\title{
A ÉTICA EMPRESARIAL E O ASSÉDIO MORAL: O FENÔMENO DO ASSÉDIO MORAL E A BUSCA DE UMA ATUAÇÃO PREVENTIVA DA ATIVIDADE EMPRESARIAL PARA RESGATE DA ÉTICA PROFISSIONAL
}

\author{
A BUSINESS ETHICS AND MORAL HARASSMENT: THE HARASSMENT \\ PHENOMENON OF MORAL AND SEARCH OF A PREVENTIVE PERFORMANCE \\ OF ACTIVITY BUSINESS FOR REDEMPTION OF ETHICS
}

\author{
Thomires elizabeth pauliv badaró de lima ${ }^{1}$ \\ Luiz eduardo gunther ${ }^{2}$
}

\section{RESUMO}

As medidas preventivas por parte da empresa apresentam-se como uma das soluções para se procurar evitar a prática de atos de assédio moral no meio ambiente empresarial, respeitando a saúde e a dignidade da pessoa humana. $\mathrm{O}$ trabalho inicia-se com um estudo sobre a ética prática profissional, embasando-se na sequência a pesquisa na doutrina de assédio moral laboral, propondo ao final a adoção de medidas preventivas e o resgate de uma ética empresarial a fim de evitar os abusos cometidos pelo assédio moral no ambiente laboral, para que se possa assim resgatar os valores éticos e a cidadania do trabalhador.

Palavras-Chave: Ética; Assédio Moral Laboral; Prevenção.

\begin{abstract}
Preventive measures by the company are presented as one of the solutions to try to avoid the practice of acts of bullying in the business environment, respecting health and human dignity. The work begins with a study of the ethical professional practice, basing on following research in labor bullying doctrine, proposing to end the adoption of preventive measures and the rescue of a business ethics in order to prevent abuse committed by bullying in the workplace, so that you can thus rescue the ethical values and citizenship worker.
\end{abstract}

Keywords: Ethics; Bullying Laboral; Prevention.

\footnotetext{
${ }^{1}$ Mestranda em Direito Empresarial e Cidadania pelo Centro Universitário Curitiba - UNICURITIBA, (Brasil). Possui 3 especializações, sendo a última em Advocacia Trabalhista no ano de 2015. Atualmente é advogada e professora universitária. E-mail: thomiresbadaro@hotmail.com

${ }^{2}$ Doutorado em Direito pela Universidade Federal do Paraná - UFPR, (Brasil). E Mestrado em Direito também pela Universidade Federal do Paraná- UFPR, (Brasil). E-mail: luizgunther@trt9.jus.br
} 


\section{INTRODUÇÃO}

A busca por um comportamento ético no meio ambiente laboral nos dias de hoje é um tema de grande necessidade atual, com o que o seu resgate é uma questão de cidadania e de dignidade diante das atrocidades advindas com a prática do assédio moral no meio ambiente laboral.

O estudo da ética é muito antigo, remonta antes de Cristo, com registro desde Sócrates, Platão e Aristóteles, mas em que pese ser um assunto milenar muitas vezes são esquecidos em vários momentos da vida pessoal e/ou profissional.

O assédio moral pode ser praticado no âmbito familiar, social, institucional, educacional, laboral, mas o foco da pesquisa do presente artigo é dentro de um contexto laboral.

O assédio moral cometido no ambiente laboral pelos empregadores, prepostos, colegas de trabalhos, são atos abusivos e que denigrem os direitos de personalidade do trabalhador.

Diante da prática desses atos tão aviltantes e que maculam o lado moral do trabalhador clama-se por um resgate ao estudo da ética e a proposta de adoção de medida de prevenção por parte da empresa.

Assim roga-se pelo resgate de valores e do respeito para com o próximo, eis que o lucro de uma empresa não pode ultrapassar a dignidade do seu trabalhador, razão pela qual o estudo da ética sempre reveste-se de vital importância no âmbito jurídico e com enfoque na visão da atividade empresarial, com o que a criação de um código de conduta para evitar a prática de assédio moral revela-se um ato de respeito para com o seu semelhante, evitando-se assim condutas discriminatórias e de violação do princípio da igualdade e da dignidade da pessoa humana, sendo acima de tudo uma questão de cidadania.

Dentro desse contexto, o problema da pesquisa que se pretende desenvolver e responder ao final é tentar delinear em que medida o estudo da ética e a adoção de medida preventiva no âmbito empresarial é importante para se evitar atos de assédio moral no meio ambiente empresarial.

O trabalho, que ora se propõe, inicia-se com um estudo sobre ética, sobretudo no contexto profissional, adentrando na sequência no assédio moral e tentando ao final buscar medida preventiva para a atividade empresarial evitar esse tipo de situação que denigre a dignidade do trabalhador e da sua cidadania.

O método utilizado no presente trabalho será o teórico-bibliográfico, que se concretiza na análise de obras, monografias, revistas especializadas, livros doutrinários e artigos científicos que tratam do assunto, assim como utilizar-se-á o método lógico de organização dialético-dedutivo, pois se pretende teorizar do aspecto geral para o particular, realizando-se análise dialética à luz das hipóteses apresentadas neste artigo. 


\section{A ÉTICA EMPRESARIAL E PROFISSIONAL}

A moral é uma forma de comportamento humano que se encontra presente na evolução do homem em sociedade, um assunto tão antigo, mas que tem que ser constantemente resgatado e relembrado no mundo atual, seja em situações vividas de cunho pessoal, assim como e principalmente na atividade empresarial, em que muitos conflitos surgem, como no caso de assédio moral no meio ambiente laboral.

Vazquez conceitua a ética como "a teoria ou ciência do comportamento moral dos homens em sociedade" (2002, p. 23), descrevendo ainda que a ética é a ciência da moral, de uma esfera do comportamento humano, não havendo uma moral ciência e sim um conhecimento moral, que seja, a moral não sendo ciência e sim objeto. Esse mesmo autor ainda declara que "não se justifica mais a existência de uma ética puramente filosófica, especulativa ou dedutiva, divorciada da ciência e da própria realidade humana moral" (SÁNCHEZ VÁZQUEZ, 2002, p. 26)

Salienta que o "problema do que fazer em cada situação concreta é um problema prático-moral e não teórico-ético" (SÁNCHEZ VÁZQUEZ, 2002, p. 17), mas a teoria pode influenciar na vida prática.

Nas relações do dia a dia da empresa podem surgir problemas práticos morais e que tocam diretamente no comportamento ético e que estão presente no ambiente laboral, precisando o empregador atentar para tais condutas com o intuito de se evitar o assédio moral e o denegrimento da personalidade do trabalhador, podendo ser classificados como atos morais ou imorais ou quem sabe até amoral.

Assim falar em assédio moral é ferir o direito de personalidade do trabalhador, não havendo um respeito da ética profissional que deve guiar toda a atividade empresarial, esquecendo-se do mandamento básico do respeito para com o próximo.

A conduta moral exige um ato consciente, um comportamento moral dos indivíduos que vivem em sociedade. Mas a moral não é somente individual, mas também social, assim como o assédio pode ser praticado de forma subjetiva, visando apenas um trabalhador, mas pode ser também de forma institucional ou coletiva.

Condutas de assédio moral praticadas no meio ambiente laboral que pode ensejar indagações de cunho ético, como em situações de humilhação, desprezo, descaso, omissão, discriminação. Exemplifica-se: quando uma pessoa discrimina o seu colega de trabalho por um motivo de deficiência ou de cor não é uma atitude eticamente correta; quando o empregador exige metas impossíveis de serem atingidas e xinga o seu empregado de incompetente e que não veste a camisa da empresa, imputando castigos e pagamento de prenda; quem humilha seus colegas de trabalho todo dia no meio ambiente laboral, fazendo brincadeiras inoportunas com o seu fisiotipo ou a sua opção sexual. Observe que esses exemplos podem ser enquadrados como assédio praticado no meio ambiente laboral e poderiam ser evitados com a adoção de uma postura preventiva por parte da empresa, com a adoção de um código de conduta empresarial, com o intuito de demonstrar qual a conduta profissional adequada no meio ambiente laboral.

Assim a ética relaciona-se com o direito, pois ambas as ciências estudam o comportamento humano, Sánchez Vázquez descreve ainda que as duas abordam o comportamento humano sujeito a normas, sendo que no campo do direito se tratam de normas 
imposta com um caráter de obrigação exterior, e, inclusive, de maneira coercitiva, ao passo que na esfera da moral as normas, embora obrigatórias, não são impostas coercitivamente. (2002, p. 33)

Que a relação da ética vai além do direito perpassando por outras ciências, como a economia, que é também objeto de estudo e de busca constante na atividade empresarial, havendo nessa ótica um "sistema econômico no qual a força do trabalho se vende como mercadoria e no qual vigora a lei da obtenção do maior lucro possível gera uma moral egoística e individualizada que satisfaz o desejo de lucro" (SÁNCHEZ VÁZQUEZ, 2002, p. 33-34), o autor ainda faz a diferenciação desse sistema com os atos econômicos de produção de bens através do trabalho e apropriação e distribuição dos mesmos, que igualmente apresentam uma certa conotação moral, pois a atividade do trabalhador, a divisão social do trabalho, as formas de propriedade dos meios de produção e a distribuição social dos produtos do trabalho humano, colocam problemas morais. (2002, p. 33-34)

A empresa não pode ter apenas a visão de busca de lucro da sua atividade, esquecendo da pessoa humana do trabalhador, sendo insuficiente para se atingir uma atuação moral e ser considerada com uma empresa ética, até mesmo porque tem uma função social a cumprir.

Para tanto o comportamento humano é manifestado em diversos planos, como o social, psicológico, jurídico, econômico, sendo que "a relação da ética com outras ciências humanas e sociais, baseada na íntima relação das diferentes formas de comportamento humano, não nos deve fazer esquecer o seu objeto específico, próprio, enquanto ciência do comportamento moral." (SÁNCHEZ VÁZQUEZ, 2002, p. 33-34)

As condutas morais é objeto de estudo da ética que está presente no dia a dia profissional e pessoal de qualquer cidadão, com o que a empresa com a implementação e treinamento de um código de conduta descrevendo o comportamento em que se espera no ambiente laboral e com respeito a ética profissional está cumprindo para com a sua função social e evitando situações de assédio moral no ambiente laboral.

Sobre o retorno à ética para se evitar o caos moral José Renato Nalini na obra Ética Geral e Profissional complementa que: "Nenhuma sociedade resistirá por tempo indefinido à insensibilidade, à irresponsabilidade, à desenfreada busca da satisfação dos instintos, sem compromisso algum com a solidariedade e com a busca da harmonia" (NALINI, 2012, p. 405), na sequência complementa a busca de uma necessária moral empresarial "Encontrará na moral empresarial a opção mais adequada à sobrevivência e aperfeiçoamento na turbulenta era do efêmero e do descartável em que a espécie humana já se encontra envolvida". (NALINI, 2012, p. 405)

$\mathrm{Na}$ sequência o autor ainda questiona se ética dá lucro, trazendo os seguintes apontamentos, descrevendo que: "O lucro virá por acréscimo se elas forem reconhecidas como empreendimentos humanos, sérios, idôneos e sensíveis a tudo aquilo que realmente importa e que não se resume ao produto que fabricam ou ao serviço que prestam" (NALINI, 2012, p. 394-395), traz ainda os comentários da autora Lúcia Maria Alves de Oliveira e Messias Mercadante de Castro sobre a gestão ética, competente e consciente no sentido de que:

Quando a preocupação com o lucro assume na empresa o papel centralizador e único de seus interesses, e não lhe permite a ampliação de horizontes participativos além de seus limites, ela corre sérios riscos e pode comprometer sua própria permanência no mercado. Essa postura tipicamente egoísta inibe oportunidades de crescimento 
profissional, não constitui o alicerce de uma saudável cultura empresarial nem propicia a criação de uma história digna de respeito. A ganancia é um vício que gera o clima ideal para propagar corrupções, sentimentos negativos e descontentamentos entre profissionais, e isso representa a soma de fatores negativos que desestabiliza qualquer empreendimento. (NALINI, 2012, p. 394)

Sérgio Pinto Martins (2015, p. 36-37) descreve que o assediador pode ser uma pessoa invejosa, com ira, ressaltando alguns dos vícios pertinentes a esse ato desumano que constitui o assédio moral:

Pode ser invejoso em relação ao fato de que o assediado é bem quisto na empresa, de que é considerado pelos superiores hierárquicos e tem uma aceitação muito grande entre os demais colegas. Não aceita que outra pessoa seja melhor do que ele na empresa.

Pode ser manipulador das pessoas, dizendo como deve ser feito isso ou aquilo, dizendo com as pessoas devem se portar.

Pode ser inseguro de perder a sua posição na empresa ou a sua liderança. Exemplo pode ser o fato de que o assediador acha que o assediado é melhor do que ele ou tem melhores aptidões para o trabalho, que o primeiro não tem.

$\mathrm{O}$ assediador tem mau humor e descarrega-o nos colegas. Se sentir que há um colega mais tímido e sujeito a aceitar a sua cólera, essa pessoa pode ser escolhida para se o assediado.

Na mesma direção em continuidade ao seu pensamento o autor afirma:

O assediado frustrado tem frustrações que são originárias talvez de inveja e ciúmes, mas também do fato de que adquiriu essa frustação no curso da vida, podendo ser originária do tempo em que vivia com seus pais.

O crítico pode ser a pessoa que critica a tudo e todos. Pode ter adquirido esse comportamento da família ou de seu pai ou mãe, se estes eram autoritários.

$\mathrm{O}$ assediador sádico sente prazer em destruir moralmente a pessoa. Faz pressão sobre a vítima.

O tirano é a pessoa que age por maldade e, às vezes, é até cruel. Humilha a vítima. Pode ser decorrente da necessidade de se impor perante os colegas. Pode ser violente e intimidador. Tem tendência de ser mentiroso.

$\mathrm{O}$ assediador sádico age de forma perversa e sem remorsos. Normalmente, entende que não tem culpa e está fazendo uma coisa boa. Pode não ter noção dos seus atos. O assediador carreirista é o que pretende fazer carreira na empresa, de galgar postos mais altos dentro da empresa e não pode se atrapalhado por outros concorrentes. (MARTINS, 2015, p. 36-37)

Com bem observa Lopes Sá "é óbvio que não escapará o profissional vitorioso dos males da inveja", pontuando ainda que:

Tal baixo sentimento sempre se faz acompanhar de atitudes imorais e antiéticas como decorrências (calúnia, difamações, traições, resistências passivas, chantagens, etc.). Todavia, a postura ética oferece remédios para se contrapor a essas mediocridades do espírito humano. 
A projeção tem seus ônus naturais e os obstáculos provêm sempre dos medíocres, dos que não conseguem pelo valor próprio se destacar no mesmo nível dos que sobrem aos graus mais elevados do conhecimento e da evidência social.

Nomes honrados podem ser desmoralizados; o que se fez durante toda uma vida, em poucos dias pode desmoronar, diante dos efeitos malévolos da ação de caluniadores, traidores, difamadores, chantagistas e intrigantes, mas é nesse particular que também os profissionais de valor podem se opor com inteligência, desde que o façam em tempo oportuno e com a energia necessária.

[...]

Existe, pois, uma ética perante a inveja, mas quando a lesão é profunda, uma estratégia especial precisa ser armada contra a sanha dos detratores. A passividade pode se gravosa. (2010, p. 153)

Nesse contexto Nalini acrescenta a necessidade de desvinculação desse egoísmo tolo, devendo investir na ética havendo sim um retorno para a atividade empresarial, evitando-se assim condutas de uma ganancia cega, devendo adotar atitudes de um solidarismo inteligente:

\footnotetext{
"Empreendedores providos de uma visão menos acanhada, atentos a um porvir destinado a melhorar as condições de vida de seus netos e bisnetos, desvinculados do imediatismo egoísta e tolo, já investem seriamente na ética. Sabem que é um projeto só mensurável no longo prazo. Surpreendem-se ao assistir retorno mais rápido em relação ao imaginável, reflexo de que a minoria pensante sabe reconhecer entre a ganancia cega e solidarismo inteligente. (2012, p. 394-395)
}

Assim observa que o estudo do assédio moral trata-se de um comportamento humano violador da imagem ética ideal dos seres humanos, com atos repugnantes e que ferem uma atitude desejável no meio ambiente laboral. Mas o que é o assédio moral no meio ambiente laboral? Em que medida há relação entre a ética o assédio moral? Passa-se na sequência a responder esses questionamentos.

\section{A ÉTICA E O ASSÉDIO MORAL NO AMBIENTE LABORAL}

Antes de adentrar na temática principal da prevenção do assédio moral objeto de pesquisa no presente artigo questiona-se há fundamento em se fazer uma correlação entre a ética e o assédio moral?

Desde já responde que sim, pois a palavra moral descrita nesse conceito não veio por acaso, eis que as condutas de assédio maculam o lado moral da pessoa, em especial na vida profissional de um trabalhador dentro do contexto empresarial.

Marie France informa que a escolha da palavra moral na sua conceituação de assédio não fora por acaso, descrevendo que tais atos se tratam efetivamente entre as escolhas do bem e do mal, do que faz e do que não faz, do que é considerável aceitável moralmente ou não perante a sociedade, não sendo possível estudar esse fenômeno sem levar em consideração a 
ética, seja diante da vítima e desse sentimento moral de ter sido maltratada, desprezada, rejeitada e humilhada, seja diante da intencionalidade praticada pelos seus agressores, se havia ou não a intenção de prejudicar. (2005, p. 15-16)

Essa autora francesa conceitua o assédio moral no local de trabalho em sua primeira obra Assédio moral: violência perversa do cotidiano como "toda e qualquer conduta abusiva manifestando-se sobretudo por comportamentos, palavras, atos, gestos, escritos que possam trazer dano à personalidade, à dignidade ou à integridade física ou psíquica de uma pessoa, pôr em perigo seu emprego ou degradar o ambiente de trabalho". (2014, p. 65)

Para Heinz Leymann aponta em seu conceito o lado não ético do assédio moral definindo como "a deliberada degradação das condições de trabalho através do estabelecimento de comunicações não éticas (abusivas), que se caracterizam pela repetição, por longo tempo, de um comportamento hostil de um superior ou colega(s) contra um indivíduo que apresenta, como reação, um quadro de miséria física, psicológica e social duradoura". (1996, p. 165-181)

Ainda os estudos de Margarida Maria Silveira Barreto realizados no Brasil há a descrição de que o assédio moral como sendo uma relação desumana e aética com a exposição de trabalhadores a situações humilhantes e constrangedoras, repetitivas e prolongadas durante a jornada de trabalho e no exercício de suas funções, em que predominam condutas negativas, relações desumanas e aéticas de longa duração, desestabilizando a relação da vítima com o ambiente de trabalho e a organização, forçando-a desistir do emprego. (2000).

Sérgio Pinto Martins na sua obra assédio moral no emprego descreve que é "preferível, portanto, o emprego da expressão assédio moral, pois visa estudar a integridade moral do trabalhador" $(2015$, p. 25$)$.

A adoção de um comportamento humano que degrada o outro ser, não importando com seus sentimentos e com a sua vida pessoal ou profissional, trazendo atitudes com a finalidade de expulsar um trabalhador do meio ambiente natural revela-se claramente uma atitude antiética, violadora do respeito e da dignidade do trabalhador, que não pode ser tratado como uma coisa.

A ética segundo Kant parte da ideia de que somos seres racionais e livres, possuindo o dever de ser tratados de forma digna e com respeito. Sandel em sua obra Justiça o é fazer a coisa certa aborda a moral kantiana em que o homem é um fim em si mesmo e não um meio ou objeto, sendo essa a diferença entre uma pessoa e a coisa, tendo o ser humano dignidade como seres racionais que são, traz a concepção da humanidade da formulação do seguinte imperativo categórico: "Aja de forma a tratar a humanidade, seja na sua pessoa seja na pessoa de outrem, como um simples meio, mas sempre ao mesmo tempo como um fim", descrevendo ainda que a justiça para Kant "obriga-nos a preservar os direitos humanos de todos, independentemente de onde vivam ou do grau de conhecimento que temos deles, simplesmente porque são seres humanos, seres racionais, e, portanto, merecedores de respeito". (SANDEL, p. 154 e 156)

Evidentemente que o assédio moral viola o respeito e a dignidade que deve possuir qualquer pessoa, sendo tratados como objeto, despido de direitos. $\mathrm{O}$ empregado não é um mero objeto e sim uma pessoa portadora de dignidade, devendo ser tratado com respeito pelos seus pares. A dignidade da pessoa humana é um fundamento da República Federativa do Brasil, descrito logo no primeiro artigo da Constituição Federal, em no seu inciso III.

Dentro desse contexto questiona: o que é ou não justo adotar no meio ambiente laboral para se evitar atos que violem a dignidade do trabalhador? O que é justou ou injusto em uma sociedade democrática de uma forma geral? O que pode ou não ser considerado um comportamento antiético dentro da empresa? Para continuar instigando eventual resposta 
desse questionamento de cunho prático traz as reflexões da Michel Sandel nesse contexto de reflexões, havendo mais perguntas e instigações do que resposta propriamente dita, razão pela qual os questionamentos se tornar pertinente a fim de se buscar essa reflexão moral:

\begin{abstract}
A vida em sociedades democráticas é cheia de divergências entre o certo e o errado, entre a justiça e injustiça. Algumas pessoas defendem o direito ao aborto, outras o consideram um crime. Algumas acreditam que a justiça requer que o rico seja taxado para ajudar o pobre, enquanto outras acham que não é justo cobrar taxas sobre o dinheiro recebido por alguém como resultado do próprio esforço. Algumas defendem o sistema de cotas na admissão ao ensino superior como uma forma de remediar erros do passado, enquanto outras consideram esse sistema uma forma injusta de discriminação invertida contra as pessoas que merecem ser admitidas pelos próprios méritos. Algumas rejeitam a tortura de suspeitos de terrorismo por a considerarem um ato moralmente abominável e indigno de uma sociedade livre, enquanto outras a defendem como um recurso extremo para evitar futuros ataques. (2012, p. 36-37)
\end{abstract}

Esse mesmo autor também diz:

Como então podemos raciocinar claramente no disputado terreno da justiça e da injustiça, da igualdade e da desigualdade, dos direitos individuais e do bem comum? Este livro tenta responder a essa pergunta.

$[\ldots]$

Expostos a tal tensão, podemos rever nossa opinião sobre a coisa certa a fazer ou repensar o princípio que inicialmente abraçávamos. Ao nos depararmos com novas situações, recuamos e avançamos em nossas opiniões e nossos princípios, revisando cada um deles à luz dos demais. Essa mudança no nosso modo de pensar, indo e vindo do mundo da ação para o mundo da razão, é no que consiste a reflexão moral. (2012, p. 36-37)

O autor nessa obra o que é fazer a coisa certa comenta diversos casos práticos, dentre os quais se destaca a situação "que ferimentos merecem o coração púrpura?" que constitui a outorga de uma medalha aos soldados feridos ou mortos em caso de guerra, descrevendo que eram considerados dignos de honra nos casos de doenças físicas, somente nessas situações em que os militares eram condecorados com o "coração púrpura". Dentro do bojo dessa explanação e caso prático relatado constata-se que as doenças psíquicas em que pese causar um maior dano ao indivíduo era sinônimo de fraqueza e não de merecimento dessa virtude, dessa honraria e homenagem. $\mathrm{O}$ autor descreve que a condecoração era apenas o sacrifício físico e não a bravura. Segue o recorte de alguns trechos, com o intuito de se buscar trazer uma reflexão e paralelo com o assédio moral no meio ambiente laboral empresarial:

Assim, o debate sobre o Coração Púrpura é mais do que uma discussão médica ou clínica sobre como determinar a veracidade do dano. No âmago da divergência estão concepções conflitantes sobre caráter moral e valor militar. Aqueles que insistem em que apenas ferimentos com sangue devem ser levados em consideração acreditam que o estresse pós-traumático reflete uma fraqueza de caráter que não é merecedora de honrarias. Os que acreditam que danos psicológicos devam ser respeitados 
argumentam que os veteranos que sofrem traumas duradouros e têm depressão profunda se sacrificaram tanto por seu país quanto os que perderam um membro em combate, e de maneira igualmente honrosa. (2012, p. 20)

Na mesma direção em continuidade ao seu pensamento da premiação polêmica sobre o Coração Púrpura o autor afirma:

\begin{abstract}
A polêmica sobre o Coração Púrpura ilustra a lógica moral da teoria de Aristóteles sobre a justiça. Não podemos determinar quem merece uma medalha militar sem que sejam questionadas as virtudes que tal condecoração realmente exalta. E, para responder a essa questão, devemos avaliar concepções de caráter e sacrifício.

Pode-se argumentar que medalhas militares são um caso especial, uma volta a uma antiga ética de honra e virtude. Nos nossos dias, a maioria das discussões sobre justiça é a respeito de como distribuir os frutos da prosperidade ou os fardos dos tempos difíceis e como definir os direitos básicos dos cidadãos. Nesses campos, predominam as considerações sobre bem-estar e liberdade. Mas discussões sobre o que é certo e o que é errado nas decisões econômicas nos remetem frequentemente à questão de Aristóteles sobre o que as pessoas moralmente merecem, e por quê. (2012, p. 20)
\end{abstract}

Com base nessa transcrição questiona-se: a dor física e aparente merece uma maior proteção em fase da dor moral? Será que a prática do assédio moral não passa também por esse tipo de discriminação? O assediado pode ser considerado como um fraco? No mundo de hoje ainda há essa cultura de diminuir a dor moral de uma pessoa?

Infelizmente em muito ambientes laborais há essa visão tradicional não considerando a pessoa humana com dignidade e sim um objeto e não como pessoa, sendo a produção mais importante do que um meio ambiente laboral sadio e livre de doenças psicológicas.

Como será demonstrado no decorrer do trabalho esses atos antiéticos devem ser evitados, pois custa caro para empresa um pensamento dessa forma, devendo sim promover a harmonia do meio ambiente laboral o que pode gerar inclusive uma maior produtividade, com a adoção de uma visão preventiva que será objeto de complementação no tópico seguinte do artigo.

Ainda sobre os riscos para empresa Marie France em entrevista disponível no site http://www.assediomoral.org/spip.php?article214 descreve que o assédio moral é um péssimo negócio para as empresas:

O assédio moral é um péssimo 'negocio' para as empresas, pois não é um método eficiente na medida em que causa perda de produtividade. Para que as pessoas trabalhem bem e produzam bastante elas precisam ter boas condições e ambiente de trabalho saudável. As pessoas precisam estar bem para produzir bem. Serem respeitadas como seres humanos. Estamos num sistema que perdeu sentido, num sistema louco. Desestruturam-se as pessoas deixando-as totalmente desmotivadas e depois se reclama que não são suficientemente eficientes, que não produzem de forma satisfatória. Isto não tem sentido! Seria necessário, pelo contrário, melhorar sempre as condições de trabalho, fazer com que as pessoas tenham vontade de trabalhar, reconhecendo e respeitando seus esforços, o que certamente, levaria a empresa a obter melhores resultados. 
Em continuidade nessa entrevista Marie-France alerta para a questão da prevenção do assédio moral como política institucional da empresa:

\begin{abstract}
Um dos argumentos que utilizo, atualmente, para ser ouvida, que dei para os políticos na França e que agora dou para as empresas, para que sejam vigilantes e que façam uma política de prevenção do assédio moral, é que o assédio moral não é produtivo, é péssimo, e custa caro. Custa caro para as vítimas porque são obrigadas a se tratar, às vezes perdem seus empregos, são, às vezes, obrigadas a recorrer a um advogado para se defender, portanto, custa caro para as vítimas.

Isto também custa caro para a sociedade porque as pessoas ficam doentes e impedidas de trabalhar. Custa caro também para as empresas porque há efetivamente, o problema do absenteísmo associado a uma grande desmotivação e perda de produtividade.
\end{abstract}

$\mathrm{Na}$ mesma direção preventiva indo para a parte final dessa entrevista adverte que o assédio moral custa caro para a empresa, implicando além da violação ética, também sanções e indenizações, afirmando que:

\begin{abstract}
Quanto dou argumentos financeiros aos dirigentes, aos donos de empresas, eles me ouvem, não ouvem sempre quando falo de respeito, das pessoas, de questão de ética, de dignidade, isto são palavras que mesmo sendo boas, eles não entendem. Mas quando falamos de números ou quando falamos: "cuidado, isto custa caro", "cuidado, é ruim para a imagem de uma empresa se isto for a público", se, por exemplo, se "comentar nos jornais que em tal empresa as pessoas sofrem e são maltratadas", isto são argumentos que hoje são ouvidos e hoje, na França, também, temos esta lei e, quando o assédio moral se produz numa empresa os dirigentes da empresa ou da organização são sancionados, às vezes, muito duramente, mas, também, o agressor é sancionado.
\end{abstract}

Diante desse contexto reflexivo observa-se que os atos de prevenção de assédio moral são de vital importância num contexto empresarial, com o que a adoção de um código de ética pode ser uma medida eficaz com o intuito de se evitar constrangimentos, ações judiciais, condenações e repercussões negativas da empresa como assediadora dos seus empregados e com denegrimento de sua imagem, razão pela qual na sequência será dado enfoque na questão da prevenção empresarial de atos de assédio moral e por fim a proposta de adoção de um código de ética para cumprir tal mister.

Assim a ética está presente no estudo jurídico do assédio moral, sendo que a resposta do questionamento proposto no início desse item como já se descreveu é afirmativa, até mesmo porque o objeto de estudo da ética é justamente a moral, que consiste no estudo e reflexão do comportamento humano, que pode escolher e optar pela adoção de um caminho do bem ou para o caminho do mal.

A atividade empresarial, como acima se aferiu também tem essa opção na concretização ou não de uma postura ética profissional, podendo exercer a sua atividade apenas visando o fim econômico, sendo a mão de obra assalariada um mero objeto para atingir o seu fim lucrativo maior, assumindo para tanto os riscos do assédio moral, ou, podese optar pelo caminho do bem e da prevenção e do respeito da dignidade dos seus trabalhadores, postura que se acredita ser a mais vantajosa para a atividade empresarial, 
conforme se complementará nas linhas abaixo, comentando um pouco mais sobre em que consiste o assédio moral e a busca de uma missão preventiva para o resgate da ética no meio ambiente laboral.

\section{O ASSÉDIO MORAL E A IMPORTÂNCIA DE SUA PREVENÇÃo NA ATIVIDADE EMPRESARIAL PARA TUTELA CONSTITUCIONAL DA DIGNIDADE DA PESSOA HUMANA DO TRABALHADOR}

Pode-se conceituar o assédio moral no ambiente de trabalho na reiteração de comportamentos degradantes a dignidade psíquica do empregado, visando com tais atitudes desestabilizá-lo e afastá-lo do ambiente laboral, ensejando com tais atos perversos, na maioria das vezes, a realização de um pedido de demissão por parte do empregado, diante do intuito principal de expulsá-lo do ambiente corporativo. (LIMA, 2016, p. 151)

Pode acontecer nas relações verticais (empregador e empregado), mas também nas relações horizontais (entre colegas de trabalho), podendo ainda coincidir essas duas formas, havendo para tanto o assédio moral na sua figura mista (horizontal e vertical).

A principal tutela do assédio moral é constitucional, diante do norte protetor do Princípio da Dignidade da Pessoa Humana, dentre outros direitos fundamentais descritos na Carta Magna, como a honra, imagem, vida privada e intimidade inerente a qualquer cidadão, que jamais poderá ser violada por ser inerente a personalidade do trabalhador.

O trabalho é um direito social fundamental como se afere da leitura do seu art. $6^{\circ}$ da Constituição Federal ${ }^{3}$, sendo também um fundamento da República Federativa do Brasil (art. $\left.1^{\mathrm{o}}, \mathrm{IV}\right)^{4}$, com o que se denota de vários dispositivos da Lei Maior a importância do trabalho na conjuntura social e econômica do país. (LIMA, 2016, p. 147)

A autora ainda descreve (LIMA, 2016, p. 148) que a proteção do trabalho vem igualmente disciplinada na Constituição Federal no capítulo da ordem econômica (artigo 170, caput, $\mathrm{CF}$ ), pois com trabalho há desenvolvimento para o país e assegura condições dignas no ambiente laboral, com o que prega um equilíbrio entre a iniciativa privada (o lucro do empresariado) e a dignidade humana do trabalhador (que fornece a mão de obra ao mercado de trabalho).

O direito ao trabalho faz parte da dignidade da pessoa humana, sendo um prolongamento da própria personalidade como adverte Evaristo de Moraes Filho:

Sendo o trabalho um prolongamento da própria personalidade, que se projeta no grupo em que vive o indivíduo, vinculando-o, pela própria divisão do trabalho social, aos demais que a compõem, representa esse direito, por si só, a raiz da própria existência do homem, pelo que lhe proporciona ou lhe pode proporcionar de subsistência, de liberdade, de auto-afirmação e de dignidade. O direito ao trabalho é a possibilidade de vir a participar cada um da produção de todos, recebendo em troca, a remuneração que lhe é devida. (1974, p. 674)

\footnotetext{
${ }^{3}$ Art. 60 São direitos sociais a educação, a saúde, a alimentação, o trabalho, a moradia, o transporte, - lazer, a segurança, a previdência social, a proteção à maternidade e à infância, a assistência aos desamparados, na forma desta Constituição.

${ }^{4}$ Art. $1^{\circ}$, inc. IV - os valores sociais do trabalho e da livre iniciativa.
} 
Mauricio Godinho Delgado (2014, p. 730) esclarece que esse cabe a comunidade jurídica encontrar caminhos interpretativos de harmonização de princípios, regras e institutos jurídicos sobre os novos desafios da tutela jurídica dos direitos da personalidade no âmbito do direito do trabalho, eis que tais direitos são objeto de tutela de qualquer trabalhador, pois além da sua dignidade humana tem o seu direito da personalidade.

Como descrito por Fábio Konder Comparato o direito do trabalho é a "pedra angular da construção de uma verdadeira sociedade democrática" (2001, p. 345), dando enfoque que não existe uma sociedade democrática sem o trabalho, dependendo inclusive para o próprio crescimento e desenvolvimento do País, seja no tocante a relação de emprego, seja para o empregador obter o lucro, seja para a subsistência e dignidade do trabalhador. (LIMA, 2016, p. 148-149)

O trabalho é de suma importância para o desenvolvimento pessoal e profissional de cada cidadão, com o que não se pode perder de vista que o empregado quando está fora da empresa é um sujeito de direito, sendo que igualmente quando está dentro da empresa continua detendo a mesma dignidade, tendo direito de personalidade, direito a honra, intimidade, imagem, privacidade, não podendo estar sujeito aos mandos e desmandos do empregador, conforme acima descrito nas doutrinas citadas e fundamentos constitucionais, até mesmo porque em qualquer ambiente que o empregado esteja continua sendo uma pessoa com a mais ampla tutela constitucional, o que jamais poderá ser desprezado pelo empregador no exercício de seu empreendimento (LIMA, 2016, p. 149), com o que o cometimento do assédio moral além de violação da própria ética, também viola flagrantemente o texto constitucional como acima apontado.

Conforme descrito no artigo $2^{\circ}$ da CLT o empregador detém o poder de direção e assume os riscos da atividade empresarial, só que evidentemente com base nesse poder diretivo não cabe a ele agir de forma abusiva na vida do empregado, a ponto de violar os seus princípios fundamentais descritos no artigo $5^{\circ}$ da Constituição Federal (CF) de 1988, incisos V e X, eis que são invioláveis à intimidade, a vida privada, a honra e a imagem das pessoas, assegurando para tanto o direito à indenização pelo dano material ou moral decorrente de sua violação. (LIMA, 2016, p. 147) ${ }^{5}$

Juan Carlos Zurita Pohlmann aponta que com a prática do assédio moral há violação dos seguintes direitos fundamentais: direito fundamental ao trabalho, direito fundamental ao meio ambiente de trabalho equilibrado, direito fundamental ao desenvolvimento e direito fundamental à saúde, pontuando esses ensinamentos no tocante ao assédio moral organizacional que igualmente denigre o meio ambiente laboral e "promove a desordem econômica; impede o desenvolvimento pessoal do trabalhador; prejudica a saúde; e acaba por impor significado do conceito de trabalho de maneira superficial aos trabalhadores." (2014, p. 73)

Eis um novo direito do trabalho com uma visão constitucional e que se preocupa com a personalidade e dignidade do trabalhador, sendo com base nesse contexto que passa a

${ }^{5}$ Art. $5^{\circ}$ Todos são iguais perante a lei, sem distinção de qualquer natureza, garantindo-se aos brasileiros e aos estrangeiros residentes no País a inviolabilidade do direito à vida, à liberdade, à igualdade, à segurança e à propriedade, nos termos seguintes: [...] $\mathrm{V}$ - é assegurado o direito de resposta, proporcional ao agravo, além da indenização por dano material, moral ou à imagem; [...] X são invioláveis a intimidade, a vida privada, a honra e a imagem das pessoas, assegurado o direito a indenização pelo dano material ou moral decorrente de sua violação; 
correlacionar a questão preventiva do estudo do assédio moral, para se tentar buscar o equilíbrio do sistema normativo ora invocado com a adoção de medidas preventivas no ambiente laboral a fim de evitar esses atos degradantes da personalidade humana e de dignidade do trabalhador advinda com a prática antiética do assédio moral.

A busca por um meio ambiente do trabalho saudável significa uma nova era do direito do trabalho que se preocupa acima de tudo com a saúde psíquica do trabalhador dentro da empresa de forma integral, já que este é um ser humano dotado de direitos da personalidade na sua mais íntima dignidade.

A empresa precisa ter consciência que o cometimento de atos de assédio moral no meio ambiente laboral é prejudicial a continuidade da atividade empresarial, diante de trabalhador cansado, desanimado, discriminado, estressado, com a produtividade diminuída, gerando indenizações e repercussões sociais desses malefícios.

Assim deve a empresa ficar alerta diante dessas condutas abusivas e adotar uma postura preventiva, além do que segundo a Constituição Federal não possui apenas uma função econômica a propriedade, mas também uma função social a ser cumprida.

A prevenção reveste-se de importância no mundo empresarial, evitando inclusive custos maiores no futuro, pois muitas vezes as práticas de assédio moral podem custar caro para a atividade empresarial, podendo até mesmo diante da gravidade dessas condutas se tornar inviável a sua continuidade.

Marie-France acrescenta no capítulo pertinente sobre a prevenção, na sua obra mal estar no trabalhado: redefinindo o assédio moral, algumas linhas sobre a ética das empresas, comentando que se uma empresa adotasse medidas éticas evitaria sim o assédio moral, mas ainda alerta que essa realidade ideal ainda é distante, sendo o discurso diferente da prática, devendo a empresa efetivamente irá atuar de uma forma mais contundente e preventiva quando constatar que os efeitos negativos do assédio moral na atividade empresarial, sendo importante ter em mente que:

Se uma empresa respeita verdadeiramente as pessoas, isto tem uma aura positiva sobre o comportamento dos indivíduos que a compõem. Porém, apesar de os gestores falarem cada vez mais em ética, existe no mundo do trabalho cada vez menos respeito pela pessoas. Não nos enganemos; mesmo que alguns deles estejam sendo sinceros quando falam de seus valores morais ou de ética, para outros são apenas palavras que lhes permitem aliviar a consciência ou salvaguardar uma boa imagem. (2005, p. 320)

Também Juan Carlos Zurita Pohlmann aponta na sua obra assédio moral organizacional, um tópico específico para a questão da prevenção do assédio moral, em seu capítulo 2, descrevendo inicialmente que:

A efetiva tutela dos direitos violados pelo assédio moral organizacional se dá pela prevenção e pela precaução. Ao se compreender esse fato, reconhece-se a necessidade de ser privilegiada uma tutela jurisdicional preventiva à repreensiva, com vias a evita-los, o que é plenamente compatível com os princípios do Direito do Trabalho. Acresce-se que a inseparabilidade do trabalho vivo no ato de entrega da força de trabalho obriga a que haja uma efetiva tutela preventiva. Por isso tentar-se-á demonstra que a tutela inibitória é mecanismo processual adequado em face do assédio moral organizacional. (2014, p. 86) 
Mais adiante esse autor ainda ressalta a importância de utilização de medidas educativas na empresa para se evitar o assédio moral, em que pese não ser por si só capaz de inibir a sua prática, mas com a educação, que abrange a informação e a conscientização pode levar a prevenção, entendendo ser indissociáveis a prevenção e educação, acrescentando ainda que "Como a conduta do assédio moral organizacional é difusa e geralmente tratada como lícita, respaldada no poder diretivo, toda medida preventiva, para ser eficaz, deve iniciar com uma estratégia educacional para levar o trabalhador à sua identificação como tal." (POHLMANN, 2014, p. 93)

Sérgio Pinto Martins igualmente ressalta a importância da prevenção por parte da empresa descrevendo que o "ideal é que a empresa faça prevenção no local de trabalho para evitar o assédio moral por parte de seus empregados." (2015, p. 33)

A fim de demonstrar a necessidade de prevenção passa-se a relatar uma história de assédio moral contada por Marie France em entrevista na Conferência e disponível no site http://www.assediomoral.org/spip.php?article214 perpassada por um executivo de uma empresa e que não aguentou a pressão sofrida:

Houve um caso na França de uma pessoa sobre a qual se colocou muita pressão no trabalho, na realidade era assédio moral mas, a empresa dizia que somente estavam lhe pedindo para trabalhar muito mais. É um caso interessante porque é um caso que se tornou jurisprudência. Era um senhor, um executivo comercial numa empresa, era um bom funcionário que tinha bons resultados. Houve, então, uma mudança de superior hierárquico: colocaram um jovem superior hierárquico recém-saído de uma Escola de Comércio que quis colocar cada vez mais pressão. Ele não suportava este senhor porque ele era mais velho, tinha 53 anos e passou então a vigiá-lo diariamente, a telefonar para saber o que estava fazendo, a perguntar por tudo, a exigir que justificasse tudo, a ridicularizá-lo porque era mais velho. Foi exigido dele objetivos cada vez mais importantes a realizar e, ao mesmo tempo, seu "setor geográfico de atuação" e suas possibilidades de trabalho foram limitadas.

Marie France relata nessa entrevista e no caso específico vivenciado por esse executivo que após o recebimento da terceira carta registrada não aguentou o assédio moral sofrido e veio a ceifar a sua própria vida:

\begin{abstract}
Após algum tempo, enviaram uma primeira carta registrada dizendo que ele não trabalhava o suficiente; pouco tempo depois, enviaram uma segunda carta registrada, dizendo que ele precisava produzir mais. Quando este senhor recebeu a terceira carta registrada, ele deu um tiro na cabeça e se suicidou, no seu carro, indo para o trabalho. Na terceira carta registrada ele escreveu: "O que vocês fizeram não é ético"
\end{abstract}

Com isso demonstra que os atos de prevenção do assédio moral são importantíssimos num código de conduta empresarial, não sendo tais situações ínfimas no meio ambiente laboral, merece uma maior tutela preventiva, eis que a adoção de tal conduta ética por parte da empresa salva até mesmo vidas, evitando doenças e indenizações, diante desse comportamento preventivo e consciente para com a dignidade de seu trabalhador.

Constata-se que falar de código de ética é falar de um comportamento para evitar atos de assédio moral no ambiente laboral, demonstrando-se assim a importância do seu estudo e 
acima de tudo aplicação dos atos de prevenção dentro do ambiente laboral para que se possa salvar vidas e evitar pessoas com doenças.

Marie-France ressalta na sua obra Mal-estar no trabalho no capítulo específico sobre a prevenção de que é preciso agir com antecedência e por em prática política de prevenção eficaz (2005, p. 311), com o intuito de se evitar chegar a esse ponto máximo acima abordado, já que a empresa possui responsabilidade por ter deixado acontecer ou não ter sabido como evitar o assédio moral, seja praticado na forma vertical ou horizontal, com o que para o bom funcionamento da empresa deve mudar tais atitudes e rever os próprios métodos de gestão, devendo os dirigentes lutar contra todas as formas de violência, adotando inclusive medidas para puní-las. (2005, p. 313).

Ainda aborda que as "medidas de prevenção consistem de início em dar aos empregados boas condições de trabalho, tomando o cuidado de prevenir o estresse." (HIRIGOYEN, 2005, p. 314), constatando ainda com a sua experiência na temática de que as empresas estão começando a ter interesse pela prevenção do estresse e pela administração dos conflitos (2005, p. 315), com o que vem de encontro com a ideia do presente artigo, quer seja, a prevenção como uma das formas de se evitar o assédio moral.

Demonstra que as empresas que se preocupam com o bem-estar dos seus trabalhadores conseguem melhores resultados em face da atividade empresarial que atuam com base no medo e estresse, até mesmo porque o "bom funcionamento de uma empresa não pode ser visto unicamente pelos resultados econômicos, mas também por seu ambiente de trabalho". (HIRIGOYEN, 2005, p. 316)

Por fim, a autora Mari-France ainda elucida algumas estratégias para se evitar o assédio moral descrevendo que:

\begin{abstract}
O primeiro passo da prevenção é educar as pessoas para que sejam corretas no cotidiano com seus companheiros de trabalho. Para isto, a empresa deve incutir normas de bom comportamento em seu pessoal e definir o que ela aceita ou não. Ela não deve importa moral a seu pessoal, mas simplesmente estabelecer limites. Deve sobretudo fazer com que cada qual preveja as possíveis consequências de seus atos sobre os outros. (2005, p. 320)
\end{abstract}

Diante do acima exposto constata-se que a proposta de uma boa forma de comportamento empresarial é a utilização de um código de conduta, descrevendo o caminho do bem e da ética dentro do ambiente laboral, assim como as consequências advindas de sua violação, mencionando para tanto a sanção legal respectiva. Mas independente da questão sancionatória legal alertada e descrita no código é necessário acima de tudo respeitar o seu semelhante no ambiente laboral.

Nalini na sua linha de abordagem ética profissional depara com o questionamento sobre um código de ética para as empresas, trazendo em seu contexto a sua importância e a seguinte resposta:

\footnotetext{
A comunicação é a chave do sucesso de um código de ética. Todos precisam saber que a empresa leva a sério a questão de sua conduta institucional - e de seus membros, servidores e clientes, além de toda a cadeia com a qual se relaciona em qualquer nível. [...] Adotar um código de ética é uma parcela do processo de se transformar o negócio em uma empresa cidadã, assim considerada aquela que reconhece a sua responsabilidade social e não se recusa a participar, ativamente, da vida comunitária. (2012, p. 390)
} 
Como apontado pelo autor com a adoção de código de ética pode ser a chave do sucesso, fazendo parte do processo de transformação da atividade empresarial em ser considerada cidadã, cumprindo para com a responsabilidade e função social.

No Estado do Paraná a Copel adota um código de conduta, havendo uma equipe para evitar esse tipo de violação ao direito da personalidade do trabalhador, trabalhando com esse tipo de prevenção, tendo profissionais responsáveis para atender tais casos, tendo inclusive uma cartilha de assédio moral, que foi criada com o "objetivo de contribuir com a formação de empregados e cidadãos conscientes de seus direitos e deveres, permitindo um clima organizacional de cooperação e respeito mútuo", trazendo em seu conteúdo a "definição do tema, dá exemplos práticos do que configura ou não assédio moral dentro da empresa e orienta como lidar com a situação caso aconteça." ${ }^{\prime \prime}$

Isso é o mínimo que se espera das empresas no dia de hoje, mas infelizmente não são todas que cumprem esse papel preventivo, com a adoção de um meio ambiente de trabalho sadio e de respeito a dignidade de cada um de seus trabalhadores.

Fica um alerta para a comunidade acadêmica da importância do tema e da sua continuidade de estudo, não podendo assim admitir a perda de valores e da solidariedade, o egoísmo e o individualismo que muitas vezes infelizmente prevalece no ambiente laboral, o que precisa ser revisto e com urgência.

É com esse espírito que se pretende resgatar a ética empresarial e o trabalhador cidadão, sem a utilização de violência física ou psicológica, respeitando a sua saúde e acima de tudo a sua dignidade, cabendo a atividade empresarial irradiar esse respeito de seus direitos, seja por uma questão social, seja por uma questão legal, diante do enfoque constitucional da dignidade da pessoa humana, clamor que se requer e pleiteia uma efetiva visão preventiva diante das graves consequências nefastas advinda com a prática do assédio moral na personalidade do trabalhador.

\section{CONSIDERAÇÕES FINAIS}

A ética profissional reveste-se de suma importância no mundo empresarial, eis que com a adoção de um comportamento moralmente correto evita-se a prática de assédio moral, evitando por conseguinte a realização de atos perversos e imorais que podem ser cometidos na vida de uma pessoa, em especial do trabalhador no meio ambiente laboral.

É necessário respeitar a dignidade da pessoa humana em todos os ambientes, o que não seria diferente no meio laboral, havendo aplicação da tutela constitucional a fim de se evitar um ambiente nocivo tanto no aspecto físico como psíquico, com o que deve o empregador proporcional um meio ambiente digno e sadio.

Fica um alerta para a comunidade acadêmica da importância do tema e da sua continuidade de estudo, não podendo assim admitir a perda de valores e da solidariedade, o

6

$$
\text { Conforme informação }
$$

descrita

no

site

http://www.copel.com/hpcopel/root/nivel2.jsp?endereco=\%2Fhpcopel\%2Froot\%2Fpagcopel2.nsf\%2F5 d546c6fdeabc9a1032571000064b22e\%2Fc4d3a793bdd4296f03257f6b006cc2a0. 
egoísmo e o individualismo que muitas vezes infelizmente prevalece no ambiente laboral, o que precisa ser revisto, razão pela qual a tutela preventiva é medida que se requer, seja para ter uma conduta ética profissional no meio ambiente laboral, seja para evitar danos maiores à atividade empresarial.

A empresa precisa ter consciência que o cometimento de atos de assédio moral no meio ambiente laboral é prejudicial à continuidade da atividade empresarial, com um trabalhador cansado, menos produtivo, gerando indenizações e repercussões sociais desses malefícios, com o que precisa estar alerta e adotar uma postura preventiva, pois a empresa segundo a Constituição Federal também tem uma função social a ser cumprida, devendo respeitar à personalidade e à dignidade de seu trabalhador.

Diante do acima exposto e no decorrer do presente artigo procurou-se responder que a adoção de um comportamento ético por parte da empresa, a instituição de uma ética profissional e principalmente através da adoção de medidas preventivas pode sim evitar atos de assédio moral dentro do meio ambiente laboral, respeitando assim a dignidade do seu trabalhador, valorizando o lado humano, podendo ser considerada uma empresa cidadã, tendo para tanto ética empresarial.

\section{REFERÊNCIAS}

BARRETO, Margarida Maria Silveira, Violência, saúde, trabalho: uma jornada de humilhações, São Paulo: Educ, 2000.

BRASIL. Constituição (1988). Diário Oficial da União, Brasília, DF, 5 out. 1988. Disponível em: < http://www.planalto.gov.br/ccivil_03/Constituicao/Constituicao.htm>. Acesso em: 26.06.2016.

BRASIL. Decreto-Lei n. 5.452, de $1^{\circ}$ de maio de 1943. Aprova a Consolidação das Leis do Trabalho. Diário Oficial da República Federativa do Brasil, Rio de Janeiro, 1 maio 1943. Disponível em: < http://www.planalto.gov.br/ccivil_03/Decreto-Lei/Del5452compilado.htm>. Acesso em: 26.06.2016.

COMPARATO, Fábio Konder. A afirmação histórica dos direitos humanos. 2. ed. São Paulo: Saraiva, 2001.

DELGADO, Mauricio Godinho. Curso de direito do trabalho. 13. ed., São Paulo: LTr, 2014.

LEYMANN, Heinz. The contempt and development of mobbing at work, European Journal of Work and Organisational Psychology, Peter Herriot, v. 5, n. 2, 1996, p. 165-181.

LIMA, Thomires Elizabeth Pauliv Badaró de; LIMA, Sandra Mara Maciel de. Assédio Moral e a Dignidade da Pessoa Humana: Os Limites do Poder do Empregador. In: Direito do trabalho e meio ambiente do trabalho I [Recurso eletrônico on-line] organização CONPEDI/UnB/UCB/IDP/UDF. Coordenadores: Everaldo Gaspar Lopes De Andrade, Luciana Aboim Machado Gonçalves da Silva, Mirta Gladys Lerena Manzo De Misailidis, 
Florianópolis: CONPEDI, 2016, p. 143-159. Disponível em: < http://www.conpedi.org.br/publicacoes/y0ii48h0/27tk8s9x>. Acesso em: 22.09.2016.

HIRIGOYEN, Marie-France. Assédio moral: a violência perversa no cotidiano. Tradução: Maria Helena Kühner, 15. ed., Rio de Janeiro: Bertrand Brasil, 2014.

HIRIGOYEN, Marie-France. Mal-estar no trabalho: redefinindo o assédio moral. Tradução: Rejane Janowitzer, 2. ed., Rio de Janeiro: Bertrand Brasil, 2005.

MARTINS, Sergio Pinto. Assédio moral no emprego. 4. ed. São Paulo: Atlas. 2015.

MORAES FILHO, Evaristo de. O direito ao trabalho. In Conferência Nacional da Ordem dos Advogados do Brasil, 11-16 ago. 1974, Rio de Janeiro. Rio de Janeiro, Asgráfica, 1974, p. 674.

NALINI, José Renato. Ética geral e profissional. 9. ed. rev., atual. E ampl. São Paulo: Editora Revista dos Tribunais, 2012.

O que é assédio moral? Disponível em http:www.assediomoral.org/spig.phd?article1. Acesso em 14.02.2015.

POHLMANN, Juan Carlos Zurita. Assédio moral organizacional: identificação e tutela preventiva. LTr, 2014.

SÁ, Antônio Lopes de, Ética profissional. 9. ed. - 2. reimp. São Paulo: Atlas, 2010.

SÁNCHEZ VÁZQUEZ, Adolfo. Ética. Tradução de João Dell’ Anna. 22. ed. Rio de Janeiro: Civilização Brasileira, 2002

SANDEL, Michel J. Justiça - O que é fazer a coisa certa. Tradução de Heloisa Matias e Maria Alice Máximo. 6. ed. Rio de Janeiro: Civilização Brasileira, 2012. 